\title{
3 \\ Benedictine Oblates: Outsiders in Community
}

For a decade following the departure of the Teresians, Maria Harispe was at the centre of a small household among the mission cottages that assembled almost by accident. By 1915 there were four missionary sisters. They were thought of as 'Spanish', although only Teresa Roca actually came from Spain. Maria Harispe and Consuelo Batiz were from the former Spanish colonies of Paraguay and Mexico. Elias Devine had come from Ireland via France and India. Their community was fragile, and their status as 'missionary oblate sisters' was informal and even contradictory, but this group of outsiders persisted and grew.

This chapter traces their transition from individuals gathered together on their own initiative into a group with a shared identity sustained by their commitment to St Joseph's and the Benedictine mission more broadly. From the strands of their outsider status they began to weave a distinctive community at the edge of the Benedictine town. In the warp and weft of daily contact with the Aboriginal women and girls, the missionary women meshed together a complex institution that linked several categories: it was part convent, part mission and training school, part government institution, and also, poignantly, part 'home'. 


\section{From Teresians to the first Benedictine oblate}

When the Teresian community split in October 1908, leaving Maria Harispe, Teresa Roca and Leonor Bargallo at New Norcia, the leadership in Barcelona told Abbot Torres that none of the sisters remaining could lead an independent house, let alone found a religious family. ${ }^{1}$ Structurally there were reasons against it. Maria and Teresa were both ayudante or lay sisters, 'helpers' to the better-educated choir sisters, and Leonor, while a choir sister, had made her final profession only in March 1905 at New Norcia, now a suspect and unstable environment from a Teresian point of view. ${ }^{2}$ Abbot Torres was not opposed to a separate community with external governance, as his dealings with the Presentation Sisters and the Sisters of St Joseph in other parts of the diocese show, but by 1908 he had little reason to trust Teresian judgement on leadership. To keep Spanish missionary women at St Joseph's, he was already thinking about another model that would reconfigure them as Benedictines. An 'Institute of Religious Oblates' would preserve the best of what the Teresian community had been doing while ensuring that the monastery was the sole authority directing the work. ${ }^{3}$

The significance of 'oblates' within the Benedictine tradition was growing in the early twentieth century. The practice, recorded in the sixth-century Rule of St Benedict, of parents making a gift or 'oblation' of a child to a monastic community meant that for centuries of Benedictine history 'oblates' were children who lived within the monastery and often (though not always) went on to become monks or nuns. The word 'oblate' also came to include others, however, of whatever age, who sought to live the Rule and to see the world through a Benedictine lens. ${ }^{4}$ Oblates were recognised by William, Abbot of Hirschau, in the mid-eleventh century and by the Lateran Council in 1215 as laypeople affiliated to a monastery.

1 Teresa Blanche to Fulgentius Torres, 18 December 1907, 'Canonical Visitation to the Community of Teresians of St Gertrude's New Norcia, October 1907', translated by David Barry, NNA 01717 (Visitation).

2 'Chronicle of the Benedictine Community of New Norcia' (hereafter Chronicle), 20 March 1905, NNA.

3 Torres to the cardinal in charge of the Sacred Congregation of Bishops and Regulars, 5 June 1908, Visitation.

4 [Benedict of Nursia], RB 1980: The Rule of St Benedict in Latin and English with Notes, ed. Timothy Fry (Collegeville, MN: Liturgical Press, 1980), chapter 59; Linda Kulzer and Roberta C. Bondi, Benedict in the World: Portraits of Monastic Oblates (Collegeville, MN: Liturgical Press, 2002). 
There was a distinguished tradition of Benedictine oblate women. Elena Conaro Piscopia, the first woman awarded a doctorate in a Western university, became a Benedictine oblate in Padua in 1665, bound into monastic life through her interests in philosophy and theology. ${ }^{5}$ More famously, the members of the community that gathered around Frances Ponzani in fifteenth-century Rome were affiliated with the local Olivetan Benedictine monastery in the $1430 \mathrm{~s}^{6}{ }^{6}$ These women were dedicated to prayer and work with the poor and came to be known as an 'Institute of Oblates'. Torres picked the same term for New Norcia. ${ }^{7}$

By the nineteenth century, Benedictine groups that had been exiled or dissolved during the upheavals of the Reformation and the French Revolution were being refounded, and, as European monasticism was revived and organised, ${ }^{8}$ provisions for oblates were codified. The AmericanCassinese Congregation wrote regulations for their oblates in 1884 that were widened to include other Benedictine communities in 1889 when Leo XIII acknowledged as secular oblates (oblati seculares) those who 'for their friendliness and good offices have been admitted as confratres of any Benedictine monastery or congregation'. ' Leo formally approved 'Statutes and Rules of Secular Oblates of St Benedict' on 17 June 1898. These guidelines did not bind members as strongly as the statutes of a religious order or congregations, but, as revised on 23 July 1904, they gave Abbot Torres a structure for new arrangements at New Norcia.

Initially, the abbot proposed that all three remaining Spanish speakers would become oblates of New Norcia. The situation was clearest for Maria Harispe, whose vows as a Teresian expired at midnight on 1 July 1909. Hours later, on the morning of 2 July 1909, Maria renewed her commitment to poverty, chastity and obedience, not in the context of

5 Francesco Ludovico Maschietto, Elena Lucrezia Cornaro Piscopia (1646-1684): The First Woman in the World to Earn a University Degree (Philadelphia: St Joseph's University Press, 2007).

6 Judith Sutera, 'The Origins and History of the Oblate Movement', in The Oblate Life, ed. Gervase Holdaway (Collegeville, MN: Liturgical Press, 2008), 33-34.

7 Oblate Formation Booklet for Oblates Associated with St Vincent Archabbey (Latrobe, PA: The Abbey, 2002), 52.

8 A. G. Dickens, Late Monasticism and the Reformation (London: Hambledon Press, 1994); Maria Crăciun and Elaine Fulton, Communities of Devotion: Religious Orders and Society in East Central Europe, 1450-1800 (Farnham, Surrey: Ashgate, 2011); Bruce L. Venarde, 'Recent Western Christian Historiography', in Encyclopedia of Monasticism, ed. William Johnston, vol. 1, A-L (Chicago and London: Fitzroy Dearborn, 2000), 596-99.

9 Oblate Formation Booklet. See also Philip Almond, 'Oblati', The Catholic Encyclopedia: An International Work of Reference, ed. Charles Herbermann (New York: Appleton, 1911), www.newa dvent.org/cathen/11188a.htm; accessed 2 April 2018. 
a religious community, but as a private undertaking witnessed by the abbot in New Norcia's parish church. Then immediately, so that the separate ceremony was remembered as part of the first, Maria Harispe made a further commitment as an oblate of St Benedict. Here she made the traditional Benedictine pledges of stability, obedience to the abbot, and life according to the Rule of Benedict. This was also probably the occasion when she changed her name: no longer Maria Teresa but now Maria Escolastica, in honour of St Benedict's sister. ${ }^{10}$ It was the feast of the Visitation, marking the journey made by Mary the mother of Jesus to Elizabeth the mother of John the Baptist. The Chronicle noted the feast in the context of Maria's new status. For those who cared to hear, the liturgies of the day carried echoes of courageous women who travelled into unknown territory. ${ }^{11}$

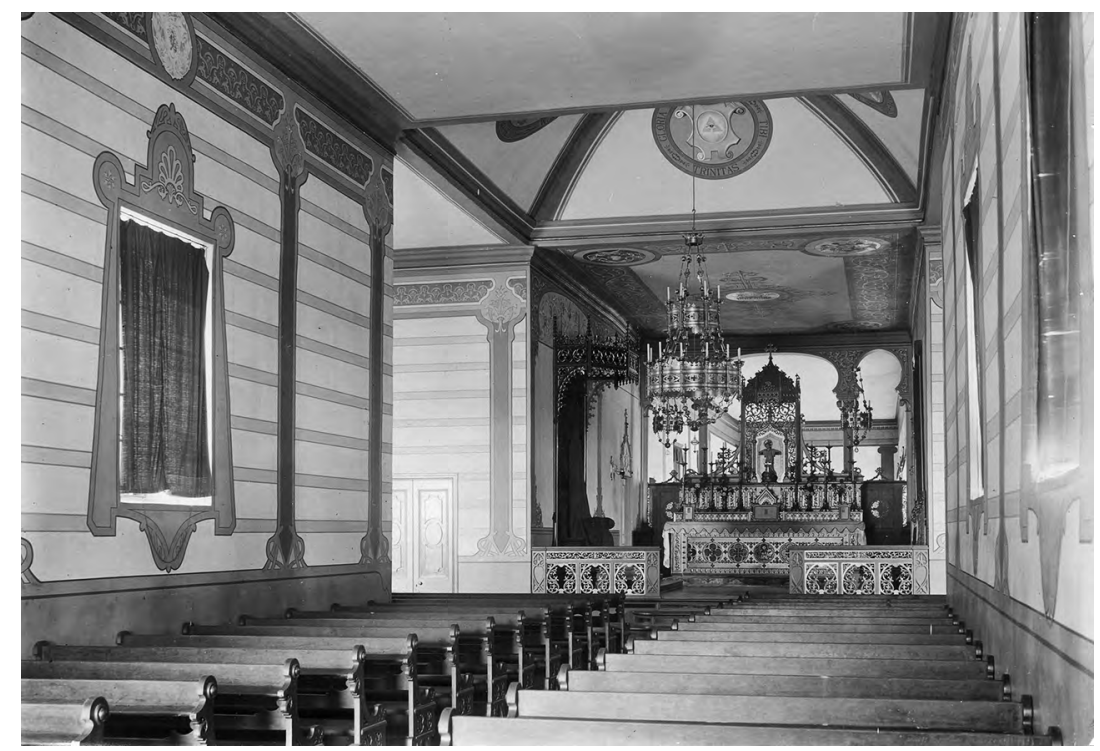

Figure 3.1: Interior of the Abbey Church 'before 1923' or as it would have been on the morning of 1 July 1909 when Maria Harispe made her profession as an oblate of New Norcia.

Source: NNA 74667P.

10 Most often she is simply Maria or Mary, but the Chronicle is clear about her new second name.

11 Luke 1:39-56. 
3. BENEDICTINE OBLATES

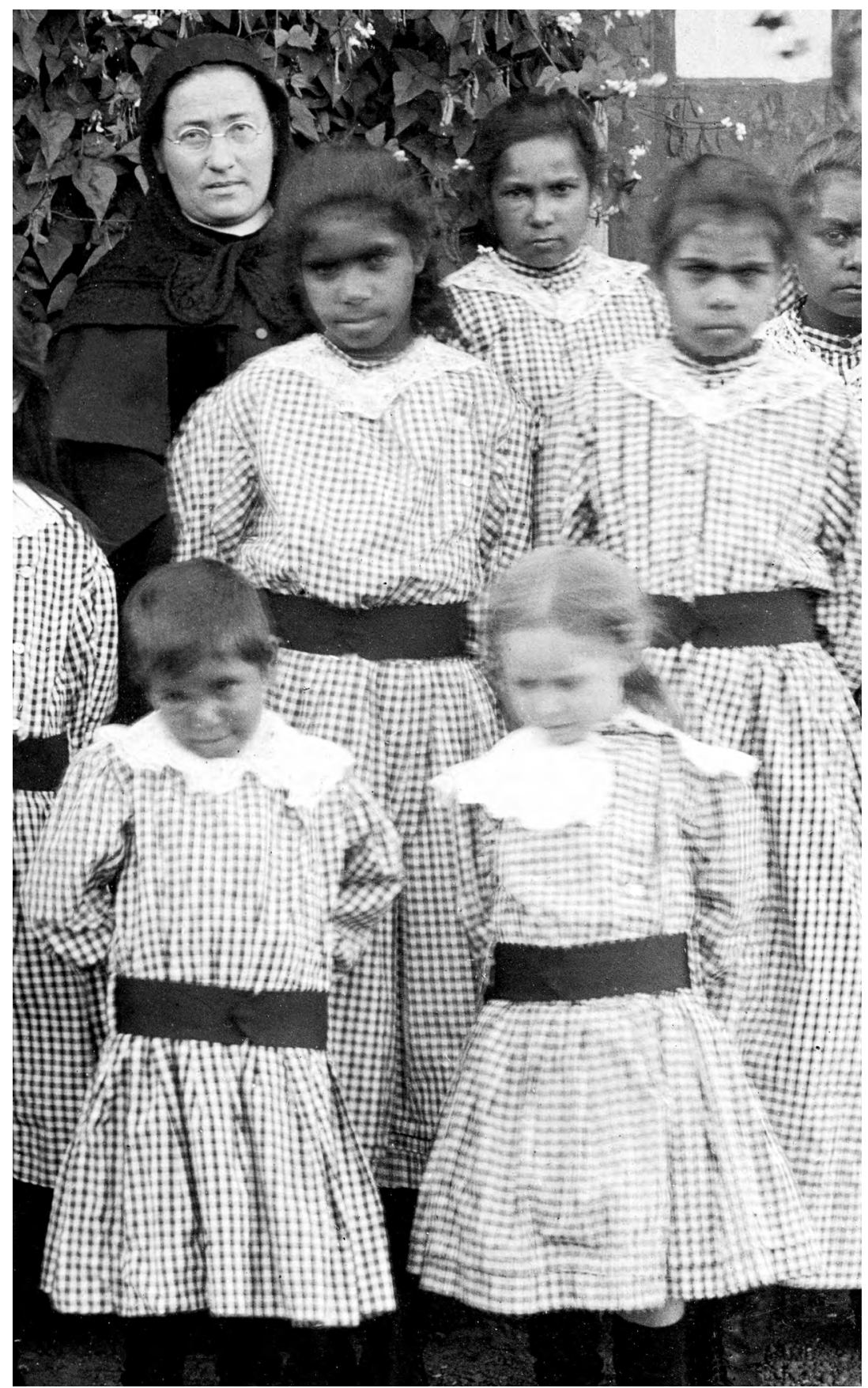

Figure 3.2: Maria Harispe c. 1915 with St Joseph's residents.

Source: Detail of NNA W7-A3-4-494. 
Maria Harispe was, the Chronicle believed, the first person in Australia to pledge allegiance to the Rule of Benedict as a secular oblate. New Norcia had other oblates already, including several diocesan priests and the painter-decorator Br Salvador Alberich, who lived within the monastic cloister, but Maria's status was distinctive. She was a woman committed to the work of the Benedictine community but living separately, with the Aboriginal people. The monastery recorded the new step carefully, hoping it augured well for Benedictines in general:

Sr Maria Harispe yesterday completed her year of religious profession, and as her vows were temporary, she is free from her Superiors in the Company of St Teresa of Jesus. Today, the day of the Visitation of Our Lady, she made vows of poverty, chastity and obedience before the Rt Rev Abbot. At once she received the scapular of a Benedictine Oblate, the Oblation following immediately. Thus it seems she is the first Benedictine Oblate in Australia, and may such an act have favourable results for Our Holy Order. The consecration to God and the offering to St Benedict took place in the church. May all be to the honour and glory of God our Lord and of our glorious Father St Benedict. ${ }^{12}$

Maria's own response is not recorded, but the move was certainly in keeping with the request she had put to Fr Altimira a year earlier, to continue to work with the Aboriginal people as a religious sister and to wear religious dress. Apart from the new Benedictine scapular, at this stage Maria continued to wear her Teresian habit. ${ }^{13}$ Teresa Roca and Leonor Bargallo had also petitioned Rome through the abbot to take a similar step. They put their request on two grounds, both concerned with preserving what they valued in their present circumstances.

Both of the grounds for transfer were relational. First, Leonor and Teresa said they feared for their religious vocations if they had to rejoin the group they had denounced in the visitation of 1907. Relationships were so damaged, they told the Roman officials, that they expected to be expelled or ostracised by 'the continual vexation which is all they can promise themselves on the part of their major superiors and even on the part of the rest of the members of their Institute'. Second, they wanted to continue to work at New Norcia, 'co-operating' with the Benedictines 'in their

12 Chronicle, 2 July 1909. For Salvador Alberich's oblate profession, see Chronicle, 1 November 1906.

13 Chronicle, 8 December 1915. 
work of evangelisation for the Australian Aborigines, taking care in particular of the education of the girls'. ${ }^{14}$ Like Maria, their commitment was to St Joseph's.

Abbot Torres supported and perhaps encouraged Teresa and Leonor in their request for a dispensation, carefully preserving copies of their letters to Rome within the report of the canonical visitation. Their situation was, however, more complex than Maria's, and negotiations inched along in Rome without much promise. Meanwhile, the Teresian leadership in Spain assumed that by allowing (or perhaps compelling) the three sisters to remain, Abbot Torres was in breach of a directive from the Congregation of the Affairs of Religious in 1909 that all the Teresians should withdraw. They 'made so much noise to obtain their return' ${ }^{15}$ that Torres was accused of impeding the congregation and began to fear he had put his own position as abbot in jeopardy. ${ }^{16}$

By January 1910, when Torres was in Rome in person, he was balancing concern about his own standing with the situation of the Teresians and negotiations on other matters, including the boundaries of the new mission in the Kimberley. He avoided the general procurator for the Benedictines in Rome and also took care not to cross paths with Cardinal Vives, the official in charge of the Congregation of Religious, until he knew how matters stood. ${ }^{17}$ When he did meet with Cardinal Vives to discuss New Norcia and the Teresians, Torres made a careful record, so there are two accounts of his interview: one in his diary and the other a more reflective letter that he sent to New Norcia's procurator, Henry Altimira, on 29 January after the decisions were made. By both accounts, when Torres met Vives he made no attempt to persuade the cardinal that women vowed to another congregation should be released to work at New Norcia. Quite the contrary: he chose his moment to detail the five

14 Petition of Leonor Bargallo and Teresa Roca to the Sacred Congregation of Bishops and Regulars, 25 May 1908, Visitation.

15 Torres to Altimira, reporting the view of Cardinal Vives, 29 January 1910, trans. Fr David Barry, OSB, NNA 01717, 23.

16 Chronicle, 25 February 1910, referring to the January letter from Torres explaining this received that day. See also The Torres Diaries 1901-1914, Diaries of Dom Fulgentius (Anthony) Torres y Mayans, O.S.B., Abbot Nullius of New Norcia, Bishop Titular of Dorylaeum, Administrator Apostolic of the Kimberley Vicariate in North Western Australia, trans. Eugene Perez, ed. Rosemary Pratt and John Millington (Perth: Artlook Books, 1987), 208-9, 210, 211.

17 Torres to Altimira, 29 January 1910; Torres Diaries, 210-16. 
years of grief the Teresians had caused him and assured the cardinal that everything was arranged 'so when they left the Sisters of St Joseph of the $\mathrm{S}$ [acred] $\mathrm{H}$ [eart] would immediately take charge of the native girls'. ${ }^{18}$

Should we wonder if there was a subtext here? To make a case against the Teresians would diffuse any suspicion that New Norcia had defied directives for their return. The presence of the Josephites as willing alternative workers was crucial, and the cardinal took the implication that the Spanish women were no longer needed. ${ }^{19}$ He concluded that the abbot should cable New Norcia with the message 'Sisters to leave for Spain - Torres'. ${ }^{20}$ This was sent on 29 January 1909.

It was important to Torres that the telegram was sent in his own name. He knew his competence to act was under suspicion, and he was at pains to note the cardinal's direction: 'You should be the one to send them to Spain without the name of my Congregation being mentioned'. ${ }^{21}$ That the public directive was allowed in his own name presumably signalled the 'fuss' about his leadership created by the Teresian lobby in Spain had come to nothing. Relief suffused Torres's diary entries that the work of the mission and his own place in it were both still well-regarded in Rome.

The telegram was, however, deliberately ambiguous. Addressed to 'Sisters', it left Maria with the choice to stay or to leave. The hope for an institute of oblates likely remained alive at the back of the abbot's mind. Torres's diary shows he remembered Maria's commitment and knew she would not want to return to South America. His letter to Fr Altimira begun on the day he issued the directive to leave acknowledged the confusion the telegram would have caused his deputies at New Norcia when they saw he had signed something requiring that the poor women are to travel to Spain. ${ }^{22}$ Reworking his notes into a fuller account, Torres walked his procurator through events that led up to the recall in a letter of 28 small pages. He began to discuss the 'principal point' of the sisters on page 5 but nevertheless spent the next 15 pages tracing events that left him reassured the Roman authorities supported him to 'continue in Australia until [he] left [his] bones there'. ${ }^{23}$ Only after establishing that context

18 Torres to Altimira, 29 January 1910; Torres Diaries, 210.

19 Torres Diaries, 210.

20 Torres to Altimira, 29 January 1910, 25; Chronicle, 25 January 1910. Torres Diaries, 211, records the cable was sent at 10.30 in the morning on Saturday, 23 January 1910.

21 Torres to Altimira, 29 January 1910, Visitation, 22; Torres Diaries, 211.

22 Torres to Altimira, 29 January 1910, Visitation, 5.

23 Torres to Altimira, 29 January 1910, Visitation, 20. 
carefully did he recount the discussion of the Teresian community itself. There was a clear implication that all three Spanish women would be willing to remain at New Norcia but that Cardinal Vives advised against it, as 'they themselves could afterwards change their minds ... and give [Torres] cause for regret'. ${ }^{24}$ After the cardinal indicated the abbot would be the one to recall the sisters, Torres was concerned 'to avoid future sorrows'; presumably, he did not want conflict with the Teresians if Maria stayed behind. While confident that two Teresians would leave, he warned he could not 'give an assurance' about 'the third who had completed temporary vows' ${ }^{25}$ Torres reported that this 'preoccupied' the cardinal who 'thought that by being the only one to stay she would be abandoned', ${ }^{26}$ but their combined judgement in the end was to leave the decision to Maria, phrasing the telegram to apply to 'Sisters'. The cardinal apparently mused: 'If the three come, fine, if the other remains, also [fine] since she does not belong to the Congregation' ${ }^{27}$ The published diary is brusque at this point, implying Torres himself saw no difference in Maria staying or going, but the letter is more considered and clarifies that he was noting the cardinal's remarks. For himself, Torres observed that thus the 'business of the Teresians has ended'. ${ }^{28} \mathrm{He}$ emphasised Teresians and left open the implication that another, different, group might replace them. ${ }^{29}$ The letter went on in some sympathy for the departing women, 'whether two or three', to imagine them waiting to embark and praying God would give them a good journey. ${ }^{30}$

Sure enough, by the time the letter arrived at New Norcia, Teresa Roca and Leonor Bargallo had obeyed the telegram and left. They departed, the Chronicle judged, 'with the greatest feeling and repugnance that there could be' ${ }^{31}$ At five o'clock in the morning on Saturday 5 February 1910, a neighbour drove the monastery coach through the dawn light to the nearest railway station at Mogumber. The women did not understand why Fr Altimira was determined to go in the other direction, to the mission house at Wyening, instead of seeing them onto the train. The Chronicle did not explain either, except to call this a 'moral impossibility' and

24 Torres to Altimira, 29 January 1910, 21.

25 Torres to Altimira, 29 January 1910, 24.

26 Torres to Altimira, 29 January 1910, Visitation, 24; Torres Diaries, 211.

27 Torres to Altimira, 29 January 1910, 25. The Torres Diaries also imply this was Torres's own view.

28 Torres to Altimira, 29 January 1910, 25, original emphasis.

29 Torres to Altimira, 29 January 1910, Visitation, 25; Torres Diaries, 211, refers to 'Sisters' in general.

30 Torres to Altimira, 29 January 1910, 26-27.

31 Chronicle, 5 February 1910. 
acknowledge that 'no-one went with them and this increased their feeling. ${ }^{32}$ Such a cool farewell would signal they were being sent from Australia, not released reluctantly on Teresian initiative.

As the abbot hoped, they did have a smooth journey. At Marseilles they received a 'consolatory' letter from Saturnina Jassá, the new Teresian superior, promising to treat them kindly. They forwarded this to New Norcia, perhaps to reassure Maria and the monks. Saturnina wrote to New Norcia directly to let the monks know when Teresa and Leonor arrived safely in Barcelona, to express surprise that only two of the missionaries had travelled, and to encourage Maria to follow. That letter has not survived, but reportedly it advised Maria to appeal to the Holy See for support to leave. The Chronicle, noting that advice, observed that the Teresians already knew Maria had decided to remain, as the letter sent to Marseilles had been addressed to Leonor and Teresa only. ${ }^{33}$

Throughout the changes, Maria kept the focus on the new commitment she had made. When the telegram recalling 'Sisters' arrived, she reminded the New Norcia monks that the order to leave did not apply to her as she was no longer a Teresian. She also reinforced the particular vow she had made to separate from her natural family in South America and simply reiterated that if allowed' she would remain. ${ }^{34}$

Maria intended to live with the Aboriginal people according to her original request. ${ }^{35}$ Torres assured the cardinal 'she could continue with the nativas', literally the 'female natives' not differentiated by age, and that the Josephites would assist her. ${ }^{36}$ The original of Torres's diary and his letter are virtually identical at this point, casting Maria as a missionary and companion to the Aboriginal women and girls and the Josephites as her helpers, presumably as teachers but perhaps in other roles also. ${ }^{37}$

32 Chronicle, 5 February 1910.

33 Chronicle, 8 April 1910.

34 Chronicle, 25 January 1910.

35 Maria Harispe to Henry Altimira, 6 June 1908, Visitation, 82; Torres Diaries, 211.

36 Maria Harispe to Henry Altimira, 6 June 1908; Torres Diaries, 211.

37 Torres to Altimira, 29 January 1910, 24; also unpublished 'Diary of Abbot Torres', NNA 2234A41-023/024. Both accounts report Torres thought Maria 'continuaría con las Nativas ayudandola las Religiosas de S. Josê. 
In terms of the public history of the Benedictine Missionary Sisters it is significant that the version of the abbot's diary published in the late 1980s reversed the initiative, claiming Maria would 'assist' the Josephites. This translation also assumed the work would be with 'native girls'. ${ }^{38}$ The misreading that downplayed Maria's responsibilities is consistent with the popular accounts of New Norcia's history that obscure the women and stress the arrival of boarding-school education. The deeper memory would be of Maria as a 'founding Mother ${ }^{39}$ whose perseverance shaped a community at St Joseph's. Linked to the monastery, integral to the mission town, and therefore also bound into the government's policies on Aboriginal affairs, St Joseph's also emerged paradoxically as separate from and distinctively 'outside' the world of the decision makers.

\section{Family of outsiders}

The particular sense of identity as a 'family of outsiders' that shaped the realities of life for the missionary women at New Norcia, no less than for the Aboriginal children in their care, is an awkward theme. The affective, emotional relationship that affirmed a 'New Norcia family' might seem pathetic in a context where assimilation carried all the racist assumptions of removing children from Aboriginal family and culture 'for their own good'. What makes the theme so resonant for New Norcia, for the Aboriginal people in the town as well as for the missionaries who worked there, is the recognition that they were oriented together towards a frame of reference that put them all outside the standard assumptions of White 'success'. In a racist context, the concept of 'family', and particularly a family of outsiders, forged bonds among the town's communities that stretched across boundaries of ethnicity and culture. To put the metaphor of the St Joseph's 'family' in context, it is useful to look back briefly to the mission's foundation in the mid-nineteenth century.

38 Torres to Altimira, 29 January 1910, 24; Torres Diaries, 211.

39 On the accounts of her death, Katharine Massam, "That There Was Love in This Home": The Benedictine Missionary Sisters at New Norcia', in Evangelists of Empire? Missionaries in Colonial History, ed. Amanda Barry, Joanna Cruickshank, Andrew Brown-May and Patricia Grimshaw (Melbourne: eScholarship Research Centre in collaboration with the School of Historical Studies, 2008), 201-14. 


\section{Early New Norcia and provision for families}

New Norcia had been imagined from the beginning as a community and an extension of the Benedictine world rather than as an institution. New Norcia's nineteenth-century founder, Rosendo Salvado, has been celebrated as a compassionate champion of Aboriginal people, building cottages for male workers and their families, not dormitories for separated children; integrating Aboriginal men into the workforce alongside the lay brothers of the monastery; and promoting the employment of women against government scepticism. ${ }^{40}$ The 'Girls House' and 'Boys House' with their dormitory accommodation had not been part of Salvado's original vision, but the monastic timetable reflected in the life at St Joseph's at the beginning of the twentieth century was probably established in Salvado's day. Théophile Bérengier, a monk of Solesmes Abbey and Salvado's agent in France, re-created the mission for French readers in $1879 .{ }^{41} \mathrm{He}$ reported that the children got up with the sun 'at the sound of the monastery bell'. Prayer and then breakfast in a common dining room were followed by routines of play, work, and study 'suitable to their age'. The ideal for Bérengier, and on into the twentieth century, was a formative lifestyle governed by monastic principles and structured according to a regular daily pattern of prayer and work.

New Norcia's reputation as the 'single success' of the Western Australian mission effort was affirmed by contemporaries and was credited to the particular dedication of the Benedictines. As Alexander Maitland, a missionary with the Church of England in India, told readers of the Perth Gazette after his visit in 1867, the monastery was the secret of the mission's success:

The faith, patience and courage which have been enabled ... to establish the monastery and Christian village of New Norcia, as we see it now, are beyond all praise. ... The success obtained by the Benedictines of New Norcia shows us clearly the only means by which a happy result may be obtained. But for Protestants it will always be difficult to establish and maintain a similar institution

40 George Russo, Lord Abbot of the Wilderness: The Life and Times of Bishop Salvado (Melbourne: Polding Press, 1980); John Harris, One Blood: 200 Years of Aboriginal Encounter with Christianity; A Story of Hope (Sutherland, NSW: Albatross Books, 1990); Anna Haebich, 'No Man Is an Island: Bishop Salvado's Vision for Mission Work with the Aboriginal People of Western Australia', New Norcia Studies 9 (2001): 20-28.

41 Théophile Bérengier, New Norcia: The History of a Benedictine Colony in Western Australia 18461878, trans. Peter Gilet (Northcote Vic.: Abbey Press, 2014). 
with our habits of comfort; and above all to find a like number of men so full of self-abnegation, patient and persevering and entirely devoted to this work of civilisation. ${ }^{42}$

The vision of an agrarian village of families surrounding a monastery did not survive the expansion of European settlement, especially not the rapid growth of the non-Aboriginal population following the discovery of gold in 1886. This transformed the struggling colony of fewer than 30,000 Europeans in 1880 into one of almost 300,000 by 1910 .

As Salvado's successor, Abbot Torres has been identified with a change in policy away from the mission work, but the reality was more complex. Although Torres did not have the easy rapport with people that had served Salvado so well, he never repudiated the mission work or his own sense of missionary vocation. ${ }^{43}$ The crucial difference was that Torres consistently underestimated the Aboriginal people at New Norcia. The Benedictine foundation at Drysdale River, still on the frontier of European contact, seemed to promise more than the complex interactions among people of mixed descent in the south. In the same way that he replaced the Aboriginal organist and choir director Paul Piramino with Fr Planas and offered Piramino a job as a shepherd, he could not see the role played by the Aboriginal women, Eliza Willaway among others, as matrons at St Joseph's and assumed he needed European missionaries. ${ }^{44}$

How much he was influenced in this by the now controversial ethnographer Daisy Bates, who visited New Norcia as Torres was settling in and who travelled with him to the north, is an interesting question. It is also intriguing to consider how much of the view of Torres as 'remote' from Aborigines has been influenced by the reports Daisy Bates published in the Western Mail. ${ }^{45}$ Salvado himself had been forced to adapt as the colony grew. Although he maintained that the mission was for working families, by the 1880s the number of unaccompanied children was increasing, and Salvado was writing to the Chief Protector impatiently protesting that he did not know or care whether their parents were alive, only that they were children in need. ${ }^{46}$

42 Alexander Maitland, Perth Gazette, 1867, cited in H. N. Birt, Benedictine Pioneers in Australia (London: Polding Press, 1911), 487.

43 Katharine Massam, 'Cloistering the Mission: Abbot Torres and Changes at New Norcia 19011910', Australasian Catholic Record 89 (2012): 13-25.

44 Katharine Massam, 'The Spiritual and the Material: Women and Work at the New Norcia Mission 1860-1910', New Norcia Studies 29 (2015): 53-61.

45 Bob Reece, "Killing with Kindness": Daisy Bates and New Norcia', Aboriginal History 32 (2008): $128-45$.

46 Salvado to Aborigines Protection Board, 4 August 1896, cited in Russo, Lord Abbot, 253, and Harris, One Blood, 300 . 


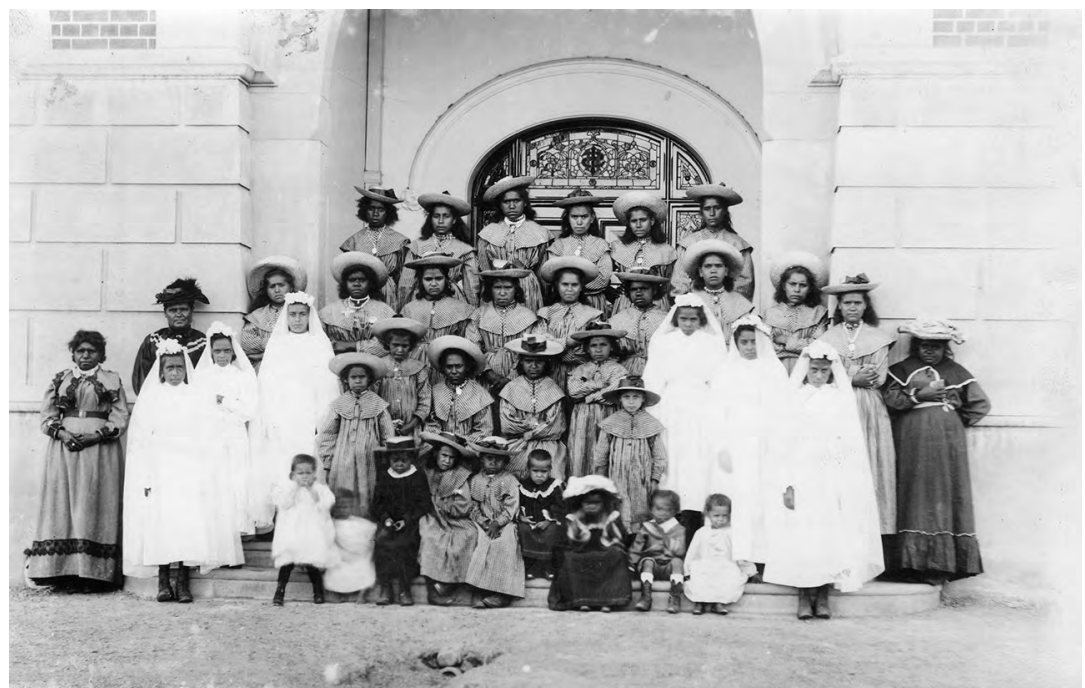

Figure 3.3: A First Communion photo c. 1908 including the Aboriginal matrons in the main doorway of St Gertrude's College.

Source: NAA w7-a3-4-496.

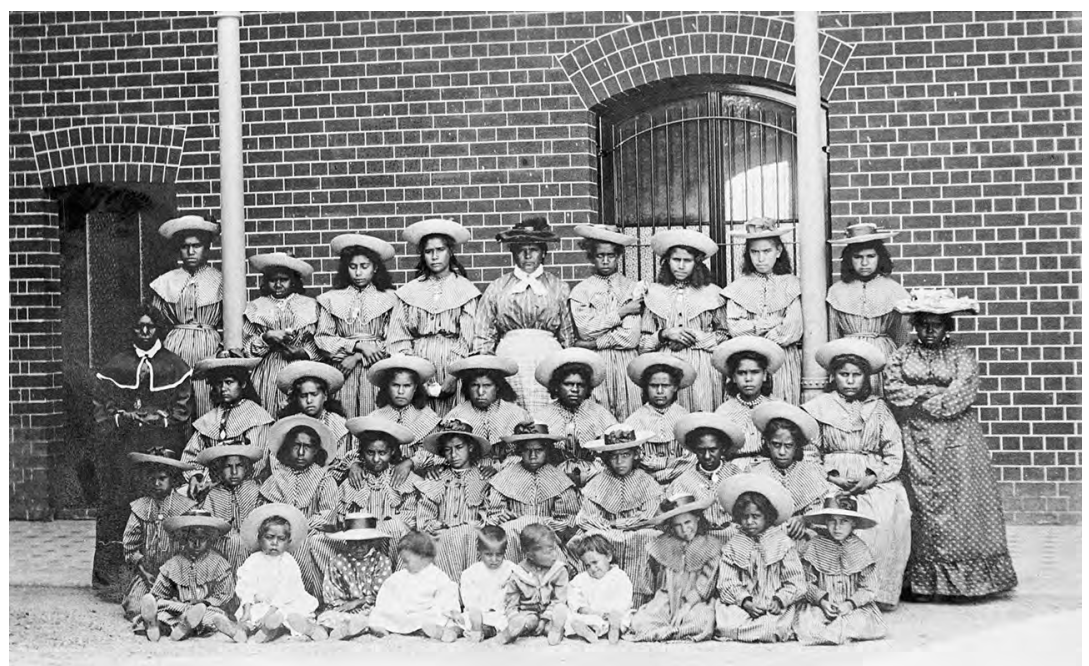

Figure 3.4: The St Joseph's girls with Aboriginal matrons on the back verandah of St Gertrude's, c. 1908.

Source: Collection of the Royal Western Australian Historical Society, State Library of Western Australia, 021317PD. 
Salvado maintained: 'This Benedictine mission of New Norcia was never intended to be, and it is not at all an orphanage', ${ }^{47}$ and yet the institutions grew and monks were appointed as superintendents. Salvado's hope for the mission did not match the colonial reality; Aboriginal people probably saw the ambiguity in Salvado's day as they continued to experience it in the twentieth century. Greater numbers of immigrants, the spread of settlement, more intensive patterns of land use, increased competition for water and food as well as increased contact with Europeans put the Aboriginal people under pressure. ${ }^{48}$ At the same time, the WA Aborigine Act 1905 made the government's Chief Protector the legal guardian of all 'Aboriginal children' under 16 years of age, regardless of whether their parents were living or dead, and whatever their family circumstances. The government's powers to remove and relocate Aboriginal people were strengthened in 1911, and again in 1936, remaining effectively in place through minor repeal and adjustment until 1967 and $1972 .{ }^{49}$ The decision to join this 'family' of outsiders at New Norcia was a choice for the missionary women, a decision they understood as a calling from God. For the children and their parents, however, St Joseph's was part of a network of compulsion. So, it is all the more striking when, within circumstances so narrowed by government regulation and community prejudice, Aboriginal girls made choices in their interactions with the missionary women. From early on, as the next section shows, St Joseph's was an ambivalent space 'between' sanctuary and coercion.

\section{Choosing and not choosing New Norcia as home}

New Norcia, in common with other missions, worked within government parameters and valued government approval, only occasionally protesting against government policy. ${ }^{50}$ In her work on the Catholic missions in the far north of Western Australia, including the 1908 Benedictine

\footnotetext{
47 Salvado to Aborigines Protection Board, 4 August 1896.

48 On the impact of the Aborigine Act 1905 (WA), see Anna Haebich, For Their Own Good: Aborigines and Government in the South West of Western Australia 1900-1940 (Nedlands, WA: University of Western Australia Press for the Charles and Joy Staples South West Region Publications Fund, 1992); South West Aboriginal Land and Sea Council, John Host and Chris Owens, 'It Is Still in My Heart, This Is My Country': The Single Noongar Claim History (Crawley, WA: UWA Press, 2009). On the economic and social changes in Western Australia: Penelope Hetherington, Paupers, Poor Relief and Poor Houses in Western Australia 1829-1910 (Crawley, WA: University of Western Australia Publishing, 2009), 129-31. 49 'List of WA Legislation', Kaartidijin Noongar-Noongar Knowledge, South West Aboriginal Land \& Sea Council, www.noongarculture.org.au/list-of-wa-legislation/; accessed 3 April 2018.

50 On Catholic mission policy nationally, see Stefano Girola, 'Rhetoric and Action: The Policies and Attitudes of the Catholic Church with Regard to Australia's Indigenous Peoples, 1885-1967' (PhD thesis, University of Queensland, 2007).
} 
foundation at Drysdale River (from 1952, Kalumburu), Christine Choo argues that government policy to remove Aboriginal children from their families could not have been implemented 'without the encouragement and compliance of Church agencies'. ${ }^{51}$ She also shows, however, that for 'many Aborigines ... there is an ambivalence in their attitude towards the missionaries and the Mission itself because for them it had become home'. ${ }^{52}$ Peggy Brock chose the word 'ghetto' to convey the effect of the missions that 'simultaneously oppressed and nurtured the communities they confined'. ${ }^{53}$ New Norcia was not unique in the cognitive dissonance that it both was and was not an orphanage, that it both encouraged family life and modelled monastic separation from it, but the choice to frame the experience of the mission as 'family' is striking in the records.

The institution as both 'ghetto' and 'home' is visible in two fragments of the Chronicle that concern the foundational phase of the work of missionary women at St Joseph's. Both point to the determining power of the relationships at St Joseph's to sustain or break the institution. They also show Aboriginal residents negotiating the boundaries of New Norcia, in one case choosing and in the other rejecting St Joseph's. Both cases make it clear that Aboriginal people expected (or hoped) to find safe haven and respect at the mission. Both are accounts of conflict, one at a distance, the other in the town itself. The accounts of the monastery's diary hint, however faintly, at an institution shaped partly by the choices of Aboriginal women, even as the same fragments highlight institutional control and narrowing options for Aboriginal people.

The first instance came to the diarist's attention in the cold, wet winter of 1907 when the Teresian community was still at full strength with seven members, among 30 other residents at St Joseph's. ${ }^{54}$ The Chronicle records on 15 June that year:

An Aboriginal girl (half-caste) 14 years old presented herself to the College when it was already night asking to be admitted. It is not known who her parents are, if they are still alive. She was in service

51 Christine Choo, 'The Role of the Catholic Missionaries at Beagle Bay in the Removal of Aboriginal Children from Their Families in the Kimberley Region from the 1890', Aboriginal History 21 (1997): 14-29.

52 Choo, 'The Role of the Catholic Missionaries', 28. See also Christine Choo, Mission Girls: Aboriginal Women on Catholic Missions in the Kimberley, Western Australia 1900-1950 (Crawley, WA: University of Western Australia Press, 2001).

53 Peggy Brock, Outback Ghettos: A History of Aboriginal Institutionalisation and Survival (Cambridge: Cambridge University Press, 1993), 1.

54 New Norcia's Annual Report to Chief Protector Prinsep, 10 September 1906, gave the number as 34 (NNA 05132). 
far from here, and having escaped from the home of her masters, she arrived here with another half-caste Aborigine. This fellow was claiming her as his, but the girl refused to follow him.

It rained again in the afternoon. ${ }^{55}$

At one level, this diary entry tells a colonial story of resistance. The girl presented herself to the mission, choosing it as an alternative to other possibilities. Most immediately, she preferred New Norcia to the man who claimed her as a wife, but the Chronicle also accepted her 'escape' from the indentured labour covered by the WA Masters and Servants Act 1892, and her long journey to make sure of it. The account shows us her initiative to separate from the man she had travelled with, but we do not know the background or the reasons: whether this relationship had any traditional standing, whether there was a rift between them, whether she intended the separation as permanent or not, whether she made a pragmatic decision for dry shelter or was drawn by the network and the prospects at New Norcia.

The house of Catholic sisters in the mission context gave the girl an option to act against the cultural expectation of marriage or male supervision, common to both sides of the racial divide. The monks' Chronicle implied support for her choice. She approached 'the College' at night, making contact with strangers and imposing herself on their routine. The colonial context is clear in the English biological term 'half-caste' imported into the Spanish account as well as in the disruption to family and social networks that meant the mission had no prospect of finding her parents and that no one else, including the girl herself, was able (or willing) to connect with her relatives either. We do not know her name, and so far the records do not let us take the story further, but the vignette of her decision suggests a resourceful young woman who judged the sisters were her best bet.

Two years later another or, just possibly, this same girl was noticed by the Chronicle. She was ' 15 or 16 years old', from elsewhere, with no known relatives, and she chose to leave New Norcia rather than 'humble herself' after an angry encounter with one of the sisters, including more than one 'cuff on the ear'. ${ }^{56}$ The sister is not named, but by 1909 there were three in the community: Maria, Teresa and Leonor. The Chronicle recounted the incident at some length, suggesting that it was unusual enough and

55 Chronicle, 15 June 1907.

56 Chronicle, 15 September 1909. 
worrying enough to warrant careful attention, perhaps not least because it prompted other girls to leave. This account also points to the colonial context and shows the permeable boundary of St Joseph's as an institution. It shows the Aboriginal girl's reaction against what she clearly judged to be unjust treatment but also underlines the mission's expectations of conformity and the frightening choice the girl had to make when 'home' came at the price of 'humbling herself'.

The incident began on a Monday, 13 September 1909; it would have been a washing day and came after the busy period of preparing for the local Agricultural Show. The Chronicle did not note any pressures in the context, however, but focused on the girl's behaviour:

15 Sept 1909: The day before yesterday a girl from the Native College behaved badly, and on being corrected behaved worse; for this reason she received a cuff on the ear from the Sister who reprimanded her. As the girl wanted to retaliate, she received a second blow. This was enough for the annoyed girl to abandon the College, and she went to the bush, since she has neither friends, relatives nor acquaintances here. Neither has she parents living or known. ${ }^{57}$

It seemed that if she had had a network in New Norcia someone might have taken her in, but without that, her only refuge was the bush. She spent the Monday night away but returned to St Joseph's on Tuesday, tired and hungry, the Chronicle noted, but 'without humbling herself for her bad behaviour'. Even when the sisters involved Torres, she remained defiant and told him she would leave again. So, the Chronicle recorded verbatim, 'Fr Abbot answered, "she might do as she wished, but that if she went to the other side of the fence she would not be received back home"'.

The Chronicle did not pause to consider how consciously the abbot called St Joseph's her 'home', or what connotation the word might have had for this child. It did make clear the leaving was not easy. She went on Tuesday morning but came back that night and drew the sisters, perhaps other sisters from the one she was in conflict with, into the compromise of letting her eat supper separately and sleep in the bakery. If this signalled some give and take, it was ultimately still on condition that she apologise. On Wednesday morning as she persisted in not humbling herself, she was sent away'. The Chronicle does not say by whom. Neither does the entry end with her departure but goes on to say that in the afternoon

57 Chronicle, 15 September 1909. 
the missionary women and the girls walked to the Agricultural Show at Yarawindah, 10 miles (or 16 kilometres) away, to see the displays. The house was still tense. That night two other girls left, one of them for the third time, expecting better prospects elsewhere. The Chronicle predicted this would be the last time she left with one of the neighbours, her 'boyfriend', but did not clarify whether this was because she had new plans or would not be allowed to return.

All in all, this is delicate and unstable material. The Chronicle gives us a privileged insight into how the mission authorities saw the situation. It is, so far as we know, the only surviving account. Created as an internal record to hold the memory of the monastic community, it is too far from the people to notice the names of the girls involved. Neither does it challenge the assumptions that a work supervisor or teacher could hit an apprentice or pupil. It does not critique the situation in which institutional conformity was the price of food and shelter. It is clear from the material that there was no room at New Norcia for girls who challenged authority or 'behaved badly'. If there was even a chance to state the case against the sister, no one found it persuasive. So, it is fair to see this incident as an example of the tightening of control and the disappearance of viable alternatives for Aboriginal people. But it is also fair to notice in the first incident that the 14-year-old actively sought and received help at St Joseph's, while in the second the girl of 15 or 16 negotiated with the institution over three days and then left rather than apologise or conform, perhaps spurring others to do the same. She did not find the relationships in the house that would have made it 'home', but the abbot's rhetoric and the sisters' efforts at compromise, as well as her own decision, backed up implicitly by the actions of two other residents, all agreed she was entitled to something better. The struggle to provide better, including the effort to resist the racist imagination that saw no future for Aboriginal people, was what had drawn Maria to New Norcia in the first place.

\section{Maria Harispe Quilliri: 'That they may regard me as a native'}

In the end we can piece together only a little of Maria's situation at St Joseph's when the Teresian community folded and guess at how successful or not she was at keeping open a space for something 'better'. She had been clear in her bid to stay at New Norcia that the monastery should 'regard me as 
a native'. ${ }^{58}$ To be happy she asked only for recognition of her vocation and permission to spend her life among the Aboriginal people. ${ }^{59}$ The Notebooks compiled and copied by later generations of Benedictine sisters preserve the difficulty of this time and affirm Maria's fidelity. Maria might have joined Mary MacKillop's Sisters if she could have been assured her work would be at St Joseph's; she was on the point of abandoning everything 'many times' but 'God preserved her spirit', 'her heroic temperament'. ${ }^{60}$ What we know from her own words is her insistent choice of the life at St Joseph's. ${ }^{61}$ If she saw herself as alone, she was also remembered as speaking often 'of the kindness and assistance given her in that trying time ${ }^{\prime 62}$ by the community at St Gertrude's College, especially by the sister whose name is lost to us who took on the teaching of reading and writing in the mornings, so that there was little change in the overall routine.

Whatever arrangements were in place, they ran smoothly and without controversy, and this in itself tells us something of Maria and her style. The 'dance of comings and goings' that Maria managed with the smallest children while the renovations at St Joseph's were underway has already been noted. ${ }^{63}$ Then for over a year, from 8 August 1910, when work on the new building was completed, nothing at St Joseph's attracted the Chronicle's notice until early November 1911. In that summer of drought the 'Sisters' pumped water from St Gertrude's to other tanks 'which the native girls use to wash the clothes'. ${ }^{64}$ The entry does not name Maria, and characteristically she falls between the categories of the 'native girls' and the Josephite 'Sisters'. But the transfer of water signalled practical cooperation between the women's institutions. Perhaps Maria had a hand in this.

Work continued, and prayer continued; we can assume that much. A visitor to New Norcia's 'rising educational centre' in 1911 told readers of the Western Mail the 'broken clans' were 'practically extinct' but noted the church was 'full of aboriginal and half-caste girls singing clear responses' ${ }^{65}$

58 Maria Harispe to Henry Altimira, 6 June 1908, Visitation, 82.

59 Maria Harispe to Henry Altimira, 6 June 1908.

60 'Origen de la Congrecacion de las Hermanas Benedictinas Misioneras de New Norcia, Western Australia' unpublished typescript from the notebooks of Sister Felicitas Pampliega c. 1921-c. 1967, transcribed and edited by Sister Teresa González, Madrid c. 1980, Archives of the Benedictine Missionary Sisters of Tutzing (ABTM) (hereafter Notebooks, Madrid), 2-4.

61 Maria Harispe to Henry Altimira, 6 June 1908.

62 Obituary, Sr Maria Harispe, St Ildephonsus College Magazine, 1925, 57.

63 See Chapter 2; Notebooks, Madrid, 5.

64 Chronicle, 15 November 1911.

65 Western Mail, 18 February 1911, 44. 
The unremarkable daily pattern included gathering in the church most evenings to pray the rosary. On Mondays and Thursdays as the girls from St Joseph's rolled through their responses to the rosary's 'joyful mysteries' they would have recalled the story of the Visitation, the feast on which Maria had made her Benedictine commitment. Most people attached particular intentions to the steady repetition of Our Fathers and Hail Marys. Probably Maria prayed frequently for the household and, knowing the abbot's concern for a teacher in the school, perhaps she was prompted sometimes to pray for companions.

\section{The household of oblates expands}

Through the years, when newspaper headlines covered the sinking of the Titanic, the battles of the First World War, the completion of the transcontinental railway from Perth to Sydney, and the development of psychological testing for children, three other women joined Maria Harispe in the work at St Joseph's. At New Norcia these years spanned the death of Abbot Torres and the election of Anselmo Catalan as the third abbot.

First, Elias Devine, born in Tipperary in 1839, made her way to New Norcia through an international network of Catholic connections in April 1912; then two of the Teresians returned, not as members of that community, but as laywomen acting on their own initiative: Maria Consuelo Batiz Abelleyra in August 1912 and Teresa Roca Lluch three years later in September 1915. These four women had each made extraordinary decisions to be nowhere else but New Norcia.

Like Maria, Consuelo and Teresa both made a commitment to New Norcia as Benedictine oblates, and on 8 December 1915, three weeks after Teresa formalised her new status, the Chronicle noted 'the Spanish Sisters appeared for the first time in public in the habit of Benedictine oblates' ${ }^{66}$ It was a feast day honouring the unique holiness of Mary the mother of Jesus under her title as Immaculate Conception, a great public holiday in Spain and a popular day for formal steps in religious communities. With three, and a mysterious fourth in the background, there was a new solidity to the small community. 


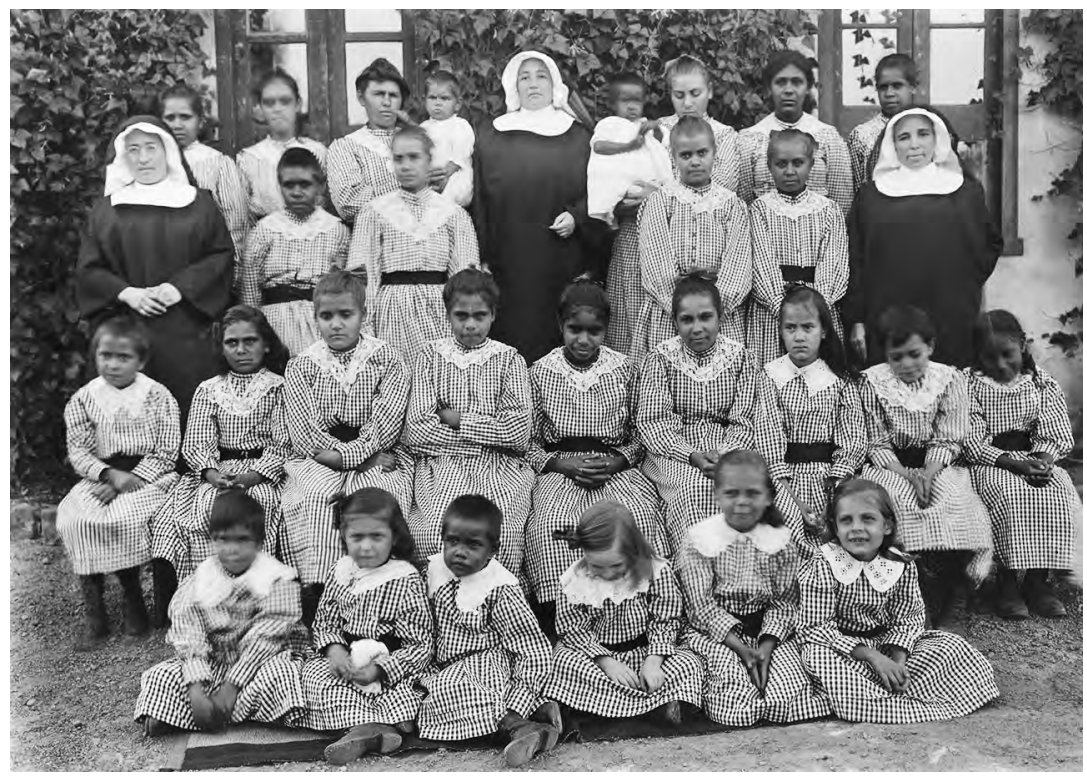

Figure 3.5: The Sisters, dressed in Benedictine habits with the St Joseph's girls, after December 1915.

The Benedictine sisters, from left to right, are Maria Harispe, Consuelo Batiz and Teresa Roca. The Drayton family recognises the baby to the left of Consuelo as Benedict Drayton, b. 1917. Source: NNA 73745P.

\section{The arrival of Mother Elias Devine, April 1912}

The four women each brought distinct skills and qualities. Crucially for the future of the school at St Joseph's, Mother Elias Devine was an Englishspeaking teacher; she was also veteran of a distinctive missionary career. Elias was 73 when she arrived 'to teach the Aboriginal girls' ${ }^{37}$ on 16 April 1912. It was the day after her birthday and a week since Easter. New Norcia made no fuss. The Chronicle noted she was 'a Carmelite' and simply recorded that she arrived with the intention of staying. ${ }^{68}$ She remained at New Norcia until her death on 20 October 1933 and 'never renounced the Carmelite habit'. ${ }^{69}$ There is a single photograph of her in an album in the Benedictine convent in Madrid. It shows her on the latticed verandah at St Joseph's,

67 Chronicle, 16 April 1912.

68 Chronicle, 16 April 1912.

69 Francisca Pardo, Interview, Madrid, May 1999, trans. Stuart Fenner. Transcript held by author. 
aged 95, supporting herself against the railing with hands resting on her furled umbrella; her gaze is direct, her face soft. Her story had been muddled over the years: Sr Francisca reported Elias was French; the Notebooks recorded she had arrived in 1917. They remembered accurately that she was a teacher, an important mentor to the early Benedictine women, and that she was never in the community photos: a clever, humble, holy, if slightly eccentric, sister.

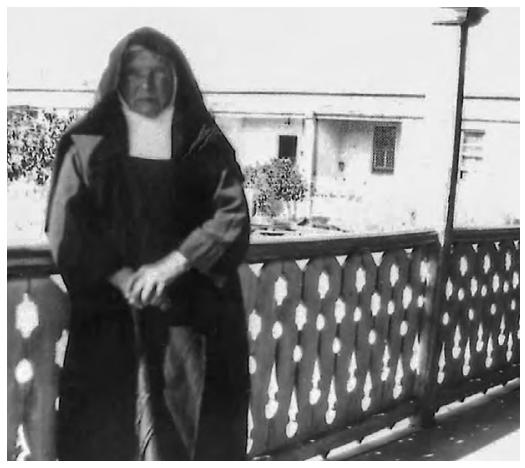

Figure 3.6: Mother Elias Devine, Easter 1933, aged 95, 'a woman of uncommon common sense'.

Source: ABTM.

At one level, Elias Devine is the most conventional of all the sisters who lived at St Joseph's. Christened Teresa in 1839, she came from a Tipperary family of 10 and was one of many Irish women who responded to the need for teachers in Catholic Australia. There is no doubt she had plenty in common with the Sisters of Mercy in Bunbury where she stayed when she first arrived in Western Australia. But there were more years and more steps to her journey than most; certainly none of the other sisters had been celebrated for missionary work in England's Catholic weekly the Tablet.

In 1900, Fr Metcalf, a priest in Pau, on the French side of the Pyrenees, had written to the Tablet to alert English readers to a new missionary college that was training candidates for India. Our Lady of the Missions at Ypres in Belgium was a 'new effort' of Mother Elias of Jesus. The work was flourishing and Metcalf saw the success as typical of Elias:

All who come in contact with her fall under the charm of her sweetness and the magnetism of her spiritual zeal, and are struck by the uncommon common sense which directs her every undertaking. ${ }^{70}$

Elias was already well-known for her educational success in the south of India, and the Tablet carried the note to update her 'many friends' in England. 
The backstory to Elias Devine's arrival at New Norcia was of an international missionary venture beginning in France in the 1850s, then centred on India, and a twentieth-century crisis that required a change in direction. As a child, Teresa Devine had been sent from Ireland to school in France and 'later' joined the Carmelites at Pau, taking the name Elias. In 1868 she was one of the two sisters who left Pau with Mother Veronica Leeves, an English woman raised in India, to found a new group at Bayonne. They wanted to draw on the Carmelite spirit for missionary work and to be 'contemplatives in action'. ${ }^{71}$ With Mother Veronica and four others, Elias established the first house of the Apostolic Carmelites in 1870 in Mangalore, in the southern Indian kingdom of Travancore, and pioneered schools and training colleges, particularly for girls. The Carmelite houses spread steadily, with three new foundations over 15 years. In 1880 Elias was superior of the Holy Angels Convent at Trivandrum ${ }^{72}$ and, with the local Carmelite bishop, co-founder of the Congregation of Carmelite Religious that developed from this house. It was recognised by Rome in $1892 . .^{73}$ The associated school was highly regarded, being accredited as a matriculation college in 1885 and recognised as a college of the University of Madras in 1899. The work of education ranged from university preparation through practical skills to earn a livelihood as well as catechetical instruction. It came to wider attention through Mother Veronica's book, Carmel in India, published in London in 1895. A profile in Europe helped foster support for their missionary outreach, and, as the Tablet reported, the community opened a missionary college in Ypres in March $1900 .^{74}$

Elias was superior of this training college and missionary novitiate from its foundation until 1905, when she made her own appeal to Tablet readers. New regulations in India had increased the training requirements for teachers, and Elias hoped for English speakers, 'earnest souls [to] share our labour of love'. ${ }^{75}$ It is likely her colleges were under pressure at this point.

71 The Congregation of the Apostolic Carmel, www.apostolic-carmel.org/index.htm; accessed 14 March 2013. Carmelites of Trivandrum, goanchurches.info/orders/carmelites-of-trivandrum-cc-r/; accessed 29 September 2020.

72 Souvenir of the Centenary of Holy Angels (Kerala, India: Congregation of the Carmelite Religious, n.d.), 106. I am indebted to Sr Phyllis and Sr Letty of the Carmelite Community who sent a copy of this work 7 May 2014.

73 All Saints College, Trivandrum, Golden Jubilee Year, www.allsaintscollege.in/allSaints/ccr. php; accessed 14 March 2013, domain expired; also Holy Angels Convent: Our History, www.holy angelstvm.org/history.aspx; accessed 29 September 2020.

74 Souvenir of the Centenary, 118.

75 Tablet, 23 September 1905, 21. 
Indian government policies were centralising and regulating schools and requiring instruction in local languages so that many private institutions were closing. ${ }^{76}$ At the same time, church authorities were promoting 'a line of action which, though most worthy in itself, did not win her commendation'. ${ }^{77}$ The records are discreet, but the dates coincide with conflict within the church over the caste system as well as strategies to promote an indigenous leadership. ${ }^{78}$ In any case, Elias resolved she should not return to India from Belgium.

Seeking advice and support, Elias heard from her friend, Fr Luigi Martelli, dean of Bunbury, that the Benedictines at New Norcia needed a teacher. ${ }^{79}$ There is no trace of their correspondence, but it makes sense that they knew each other. Martelli had been born in Goa to Italian parents and educated in India. Arriving in Western Australia in 1881, he knew New Norcia well through his uncle Fr Raffaele Martelli, parish priest of Fremantle and later of Toodyay and a close friend of Salvado. ${ }^{80}$ Thus, Mother Elias made her way to Western Australia. New Norcia would remember how she treasured the memories of India, how 'her face would glow with admiration of a noble people' as she told stories, but how she had 'sought another field of labour'. ${ }^{81}$ Was it remarkable that the Teresa Devine of Tipperary, Trivandrum and Ypres joined the community at New Norcia? Or was this simply a predictable enough variation on the general theme of commitment that led Catholic women to missionary work and life in religious communities in far-flung countries?

For the community at St Joseph's there was nothing unusual in a journey across the globe, and all the signs are that Elias moved smoothly into the work of the mission. Perhaps the most intriguing aspect of the story is the strong, but misleading, tradition among the Benedictine women that she arrived in 1917. How did memory slip out of agreement with the Chronicle and other records by five years? The likely explanation is simple

\footnotetext{
76 'Introduction to Lord Curzon's Education Policy', Krishna Kanta Handiqui State Open University, kkhsou.in/main/education/education_policy.html; accessed 18 March 2014.

77 Brother Sebastian, 'Mother M. Elias', St Ildephonsus College Magazine, 1933, 47.

78 Paul Pallath, The Catholic Church in India (Kerala: Oriental Institute of Religious Studies, 2010), 165-69; Kenneth Ballhatchet, Class, Caste and Catholicism in India, 1789-1914 (London: Curzon Press, 1998), 40-46.

79 Sebastian, 'Mother M. Elias', 47.

80 John Kinder, 'I'm Writing Simply to Say I Have Nothing to Write About: The Martelli Letters 1854-1864', New Norcia Studies 19 (2011): 19-33; John Kinder and Joshua Brown, Canon Raffaele Martelli in Western Australia, 1853-1864: Life and Letters (Northcote, Vic.: Abbey Press, 2014).

81 Sebastian, 'Mother M. Elias', 47.
} 
enough and entwined with the story of Consuelo Batiz, also a teacher. It was Consuelo's story that shaped the popular understanding that New Norcia was without a teacher, not in 1912, but in 1917.

\section{The return of Mary Consuelo Batiz Abelleyra, 1912}

Mary Consuelo Batiz is an elusive and compelling figure. One of the original party of Teresians and widely respected as the 'director' of the school, her recall from the troubled Teresian community in 1907 struck everyone at New Norcia as a mistake. ${ }^{82}$ We can only imagine the reactions of the people who had grieved Consuelo's departure when, five years later, on 5 September 1912, they assembled to welcome her back.

We do not know how contact was re-established. In the first phase of her recall to Valencia, the Chronicle surmised the Teresians were intercepting letters to her from New Norcia. ${ }^{83}$ But within the small talk of the Spanish congregation the news that Maria Harispe had remained in Australia would certainly have reached her. It is tempting to speculate that somehow news of Elias encouraged her and that the promise of a new community prompted her move, but the records leave us guessing. Certainly, the monks at New Norcia had no warning.

The Chronicle was confused and surprised by news of her journey, thinking at first that her telegram was from Torres, but her arrival was recorded as a stately homecoming:

At two in the afternoon there arrived from Spain, Sr Consuelo Batiz who five years before left the Mission recalled to Spain by her superiors; but today she returned, probably never to leave again as she is freed from her religious vows that bound her to the Congregation of the Company of St Teresa of Jesus. ${ }^{84}$

Consuelo's return was a powerful vindication of the glowing 1907 assessments of her love for the Aboriginal people and their regard for her. To make the journey from Spain to Australia a second time, and to return

82 See Chapter 2.

83 Chronicle, 8 November 1907.

84 Chronicle, 5 September 1912; that the monks thought her telegram announcing her return was from Torres. Chronicle, 27 August 1912. 
as a single woman, formally separated from the missionary congregation that had sponsored her work, gave that work absolute priority. As the next chapter shows, her second sojourn ended badly, but it began in hope and confidence.

Acknowledging her new, more vulnerable status, Consuelo negotiated a contract with the abbot. Torres agreed the monastery would feed and clothe her while she was in residence. This was standard. But we have her later word that he also agreed that should she ever leave New Norcia he would pay her fare to Mexico or to Spain, as well as a retrospective wage of $£ 1$ per week. This was exactly half the basic wage of 8 shillings a day for men, and just under the average annual earnings of $£ 56$ for female factory hands in Western Australia in 1912. ${ }^{85}$ According to evidence given at the Roth Royal Commission in 1905, wages paid to Aboriginal men working on the farm at New Norcia ranged from $£ 1$ a month up to $£ 18$ s a week. ${ }^{86}$ The verbal contract between Torres and Consuelo reflected the good working relationship they seem to have enjoyed. Consuelo was adamant the contract was agreed, but she had no cause to mention it while Torres was in charge.

Consuelo had never met Maria or Elias. When Maria first joined the Teresians, Consuelo was already at New Norcia, and when Maria arrived Consuelo had already been recalled. The two missionaries were of the same generation, Consuelo at 34 years to Maria's 31, they had both come from South America to Spain to join the Teresians, and both had stood out against the congregation's leadership. Elias was twice their age but shared the capacity for bold decisions and the priority of a missionary call. Perhaps they had corresponded. Undoubtedly, Consuelo's friends at the mission had talked about her.

85 Commonwealth Bureau of Census and Statistics, Official Year Book of the Commonwealth of Australia Containing Authoritative Statistics for the Period 1901-1913, no. 7 (Canberra: Government Printer, 1914), 469. On the contract, Catalan to Northmore and Hale, 17 November 1917, Catalan Correspondence 1917, NNA 01419/70.

86 Evidence of Fr Edmund McCormick, New Norcia, 'The Aborigines Question: Evidence Taken by Dr Roth', Western Mail, 20 February 1905, 19-20. 


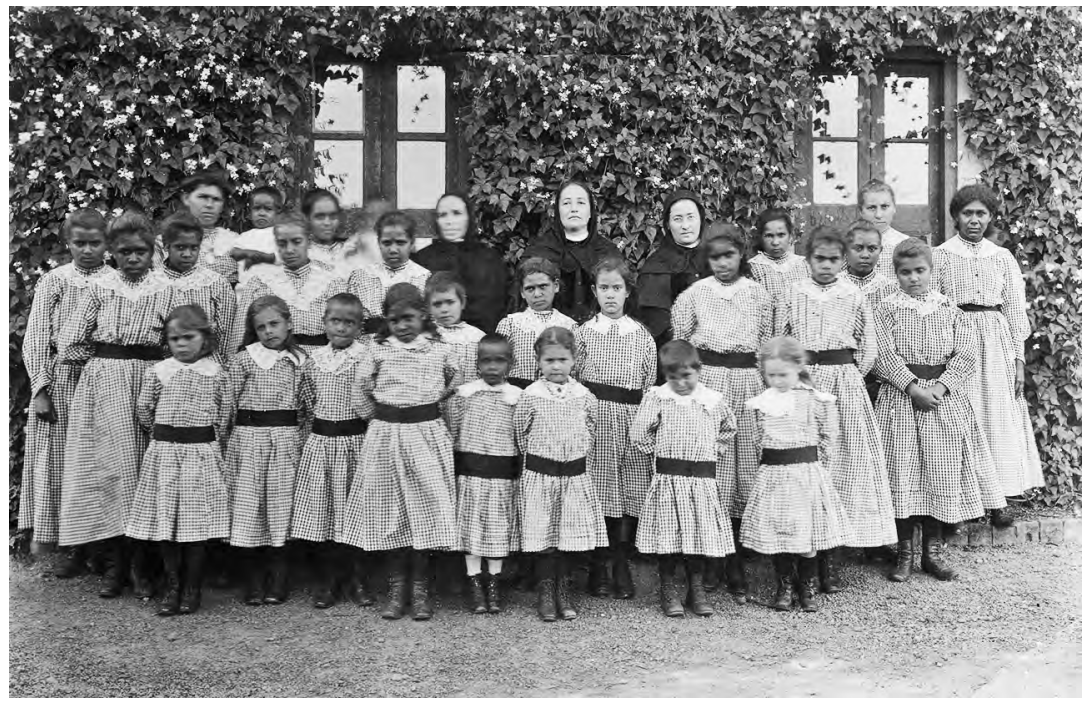

Figure 3.7: Consuelo (centre) with Teresa (left), Maria (right) and residents of St Joseph's, after September 1912 and before December 1915.

Source: NNA W7-a3-4-494.

Consuelo's role at the mission had already been contested once; her affirmation in the town had contrasted with tension in the Teresian community. How much that memory coloured her return and the subsequent record is impossible to say, but the Notebooks compiled without direct contact with Consuelo are against her. The view preserved among the Benedictine sisters was that Consuelo 'had exceptional talents for the leadership of the Orphanage, ${ }^{87}$ but her style of religious life was out of order. We are not told how she offended, just that, in a phrase that echoes the Teresian complaints, 'her behavior as a religious sister was undesirable' ${ }^{88}$ Maria's initial joy in the arrival of another companion was short-lived. More than that, for Maria, working with Consuelo became 'a true Calvary'. ${ }^{89}$ The word is stunning. Its heavy connotation of unjust suffering hangs in the air. It underlines the memory of Maria's holiness as it loads the dice against Consuelo. Perhaps the verdict in the Notebooks was misinformed; it was certainly retrospective.

87 Notebooks, Madrid, 6. 'Esta Hna de nacionalidad mixicana tenia dates extraordinarios para gabernar el Orfalinato que ya estaba casi constuido. No obstante su conducta como religiosa era indeseable. Con sus rechazos por parte de los Superiores y con su terco y destructivo teson permanecio en la Mision 5 años hasta 1917. Estos años fueron de verdadero calvario para Hna Maria.'

88 Notebooks, Madrid, 6.

89 Notebooks, Madrid, 6. 
On her return, Consuelo slipped back into her role as 'director' of the school, bringing the resources and education of a former choir sister to the work. The transition did not disturb the routine enough to cause the Chronicle to comment, so we have to surmise most of what it meant in the day-today. The elderly Elias was active in her support, and sometimes to the fore, as when she coached the girls in songs and dances for a concert with the French-speaking soprano Antonia Dolores Bettini in 1915 or when she engaged the English-speaking Travelling Inspector in $1913 . .^{90}$ The report prepared by George S. Olivey of the state's Department of Aborigines and Fisheries gave a rare overview of the institution. He met and talked with the three sisters and affirmed enthusiastically that 'all were heart and soul in their work, taking the greatest interest in the welfare of their charges'. ${ }^{91}$

Before we turn to consider Olivey's report, there is one more sister to acknowledge in this first expansion of the community. Teresa Roca had spent six years at New Norcia before her departure 'under obedience' in $1910,{ }^{92}$ and at 47 years old she was a generation older than the other former Teresians, an experienced lay sister with some early training as a nurse. ${ }^{93}$ The fact of her return in 1915 is almost all we know of her motivation, but it heralded a commitment that was to last four decades.

\section{The return of Teresa Roca Lluch, September 1915}

The story of Teresa Roca's journey underlines her determination as well as a fearless trust in God. She sailed out of Barcelona in 1915, undeterred by the difficulty of wartime travel as a single woman without proper papers. The sisters who knew her remembered that she insisted on sailing even though 'the superior had a headache and forgot to bring her passport to the ship. ${ }^{94}$ There were no formal passports at the time, but the memory enshrines an ongoing connection between Teresa and the congregation that had, perhaps reluctantly, released her from vows. It paints the superior as a little vapid, and it highlights Teresa's resolve.

\footnotetext{
90 See Chapter 4.

91 George S. Olivey, Travelling Inspector, 'Report on New Norcia Mission', State Records Office of Western Australia (SROWA) S1644 cons652 1913/0213.

92 Notebooks, Madrid, 2-3.

93 Pax, 3 February 1953, n.p. Newspaper clipping, ABTM.

94 Francisca Pardo, Interview, Madrid, 31 May 1999.
} 


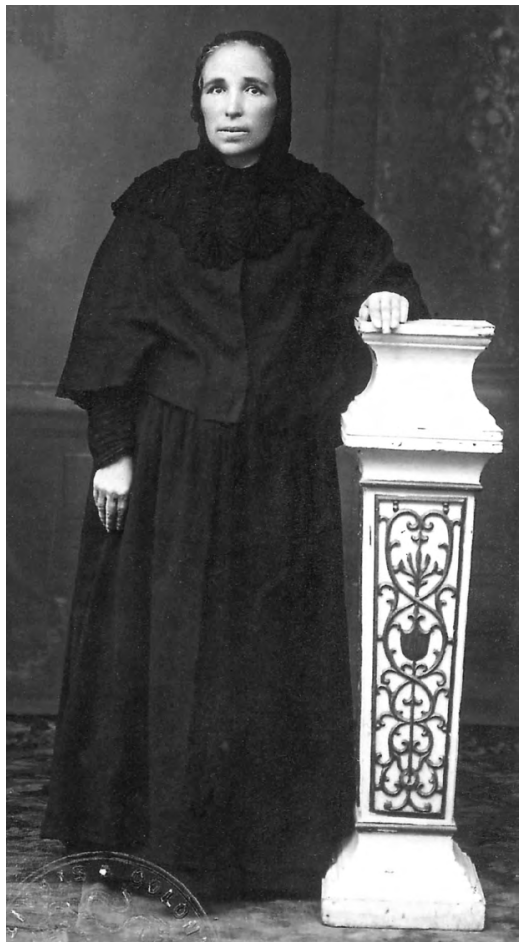

Figure 3.8: Teresa Roca, one of the original Teresian community, remembered in the Notebooks as setting out again in 1915 'without fear and with great confidence in God'.

Source: ABTM.
The community's Notebooks imply she had spent the five years of her absence seeking a dispensation from her vows and permission to travel. When finally she could make the journey, she felt the voyage nearly killed her. Ill with 'dizziness and fear' she haemorrhaged 'to the brink of death' as they arrived in Singapore. ${ }^{95}$ Then, with no documents, a dubious nationality, and, the Notebooks record tellingly, not able to speak English, 'a language necessary for defending herself' (idioma [im]presinible para su defensa), ${ }^{96}$ she was detained as a suspected German spy. An elegant black-and-white photograph taken as a memento for her family shows a serene face and graceful lace veil that might have evoked stereotypes of espionage more readily than missionary hopes. She was kept under surveillance at a convent. Eventually, the authorities made contact with New Norcia and Teresa was permitted to sail on.

With a firm emphasis on her missionary identity, she travelled as Sister T. Roca. ${ }^{97}$ The cloud of police suspicion had not lifted, however, and when the Charon arrived at Fremantle on 15 September 1915, she was not permitted to leave the port unaccompanied. ${ }^{98}$ There was no one to meet her, so a stewardess ( una azafata) was assigned to take her to the address she pulled from her memory. ${ }^{99}$ At the Benedictines' house in the city, 1 Murray Street,

95 Notebooks, Madrid, 7.

96 Notebooks, Madrid, 7.

97 West Australian, 15 September 1915, 6.

98 Notebooks, Madrid, 7.

99 Sr Francisca Pardo, Interview, Madrid, 31 May 1999; Sr Teresa González, Interview, Madrid, 10 July 2004. 
West Perth, the monks vouched for her persuasively. Uncertain about the day of her arrival, they had nevertheless come from New Norcia to collect her. 'Finally', the Notebooks declare, 'she arrived at the Mission she so much desired'. ${ }^{100}$ But the haemorrhages of the voyage returned, as severe as before. The timing suggests a difficult menopause. We hear nothing further and perhaps local knowledge came into play once she reached the community of women. The Notebooks made a different link, implying that New Norcia itself was the remedy. They preserved the memory of haemorrhage with an eye on God's Providence, explaining that Teresa 'skirted death for several days', until 'it was not her time and she was able to work in the Mission for 40 more years'. ${ }^{101}$ The Chronicle had nothing to say about her return at all but noted carefully two months later: 'Sister Teresa Roca made her oblation at the hands of Father Prior Roberto Bas' on Sunday 14 November 1915. ${ }^{102}$ The prior was deputising for the newly elected Abbot Catalan, still on his way to New Norcia from Manila.

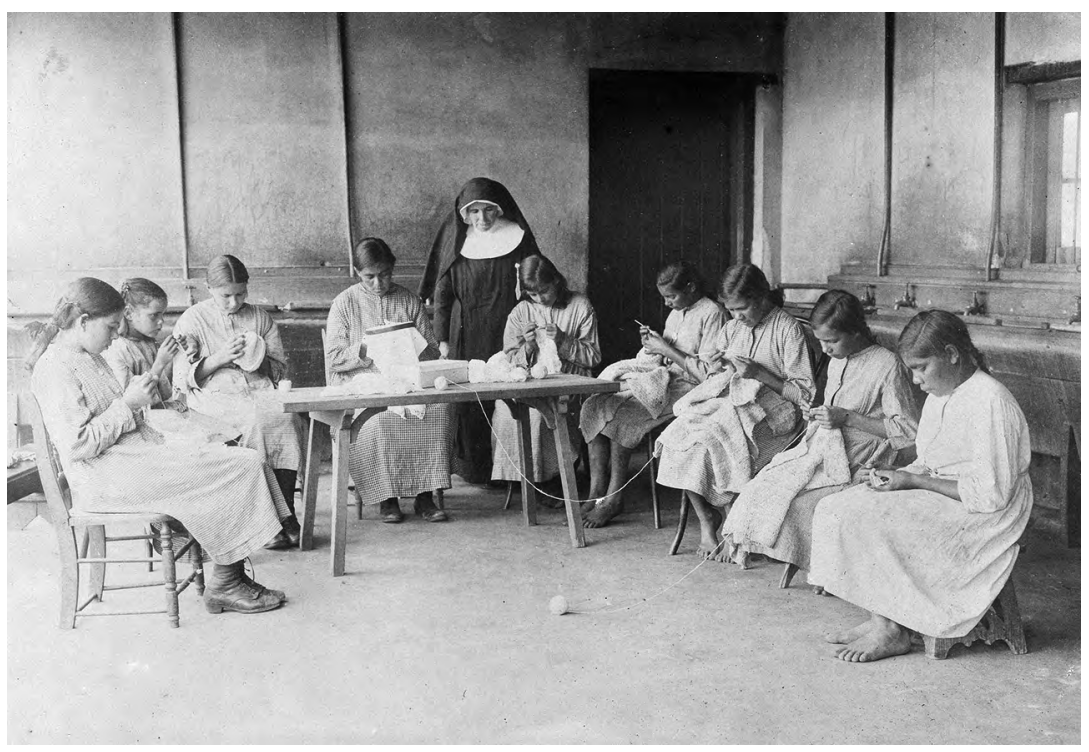

Figure 3.9: Teresa Roca and Aboriginal girls working at embroidery and crochet in the sewing room.

Source: NNA w7-a3-4-495.

100 Notebooks, Madrid, 8.

101 Notebooks, Madrid, 8.

102 Chronicle, 4 November 1915. 
Maria, Consuelo and Teresa as Benedictine oblates and Elias, the missionary Carmelite, had assembled as a community. Responsibilities were divided broadly. The monastery's summary of the leadership St Joseph's in 1913 noted 'three Sisters in charge'. ${ }^{103}$ Torres does not tell us who did what but summarises 'one nun takes charge of school, another teaches needle and fancy work, and a third superintends all other work and directs the conduct of the girls in general'. ${ }^{104}$ When a fourth arrived, gifted in handcraft and trained for domestic work, she added to the workforce outside the formal classroom. The sisters were all 'of good experience'. ${ }^{105}$ Now they found themselves together in a shared commitment to St Joseph's. The complex of buildings that constituted St Joseph's at this time, newly renovated, enlarged and enclosed in the shadow of St Gertrude's, is almost another character in the story of the Benedictine sisters. The next chapter assembles a picture of the institution itself. St Joseph's was as much metaphor as it was location. On the edge of the mission town, St Joseph's helped shade emotional resonances and establish a pattern of life.

103 'New Norcia Mission. Annual Report for Year ending 30 June 1913', SROWA S1644 cons652 $1913 / 1273$.

104 'New Norcia Mission. Annual Report for Year ending 30 June 1913'.

105 'New Norcia Mission. Annual Report for Year ending 30 June 1913'. 
This text is taken from A Bridge Between: Spanish Benedictine Missionary Women in Australia, by Katharine Massam, published 2020 by ANU Press, The Australian National University, Canberra, Australia. 